The Free Internet Journal for Organic Chemistry
Paper

Arkivoc 2018, part ii, 9-16

\title{
Computational study of hydrido boronium dications and comparison with the isoelectronic carbon analogs
}

\author{
Golam Rasul, George A. Olah, and G. K. Surya Prakash*
}

Loker Hydrocarbon Research Institute and Department of Chemistry, University of Southern California, University Park, Los Angeles, CA 90089-1661

E-mail: gprakash@usc.edu

Dedicated to Prof. Kenneth Laali on the occasion of his $65^{\text {th }}$ Birthday and life-long contributions to chemistry

Received 03-14-2017

Accepted 06-19-2017

Published on line $07-30-2017$

\section{Abstract}

Calculations at the CCSD(T)/cc-pVTZ level show that higher coordinate, hydrido boronium dications are viable species despite their charge-charge repulsion. Structure and bonding of the studied boronium dications are discussed and are compared with their isoelectronic carbon analogs. Although the studied boronium dications are thermodynamically unstable towards deprotonation, their computational characterization supports their transient existence.

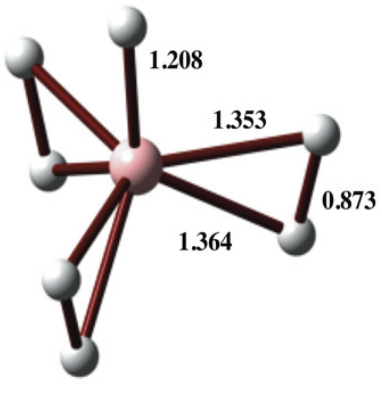

$$
\mathrm{BH}_{7}^{2+}\left(\mathrm{C}_{3 \mathrm{v}}\right)
$$

Keywords: Hydrido boronium dications, higher coordinate, two-electron three-center bond, isoelectronic carbon analog 


\section{Introduction}

Main group hydrido cations and dications have been a subject of numerous experimental and theoretical investigations. ${ }^{1-6}$ A while ago we have reported ${ }^{7}$ the calculated structures of parent hexa- and heptacoordinate boronium ions, $\mathrm{BH}_{6}{ }^{+}$and $\mathrm{BH}_{7}{ }^{2+}$, respectively, with two and three two-electron three-center $(2 \mathrm{e}-3 \mathrm{c})$ bonds. The structures were found to be isostructural with their isoelectronic carbon analogs, $\mathrm{CH}_{6}{ }^{2+}, 8,9$ and $\mathrm{CH}_{7}{ }^{3+}, 10$ respectively. We have also previously investigated the structures and energetics of $\mathrm{BH}_{n}{ }^{2+}(\mathrm{n}=1-8)^{11}$ and $\mathrm{B}_{2} \mathrm{H}_{2} \mathrm{n}^{2+}(\mathrm{n}=1-4)^{12}$ dications at the MP2/aug-cc-pVTZ and QCISD(T)/6-311G** levels, respectively. In continuation of our study of higher coordinate onium ions, we have carried out a study on the structure and bonding of higher coordinate hydrido boronium dications. For comparison, all the structures were calculated at the same $\operatorname{CCSD}(T) / c c-p V T Z$ level.

\section{Results and Discussion}

Gaussian 09 program 13 was employed for geometry optimizations and frequency calculations. The geometries were first optimized at the MP2/cc-pVTZ, level. Vibrational frequencies at the MP2/cc-pVTZ//MP2/cc-pVTZ level were used to characterize stationary points as minima (NIMAG (number of imaginary frequency) $=0$ or transition state NIMAG = 1) and to compute zero point vibrational energies (ZPE), which were scaled by a factor of 0.96.14 The MP2/cc-pVTZ geometries were further optimized at the CCSD(T)/cc-pVTZ level. CCSD $(T) / c c-p V T Z$ optimizations have been performed with the CFOUR program. 15 Computed energies are given in Table 1.

\section{$\mathrm{BH}^{2+}(\mathrm{n}=3-8)$ systems}

In line with previous calculations at the MP2/aug-cc-pVTZ level, 11 our present calculations at the CCSD(T)/CcpVTZ level also shows that the $\mathrm{C}_{2} v$ symmetric structure 1 is a viable minimum for $\mathrm{BH}_{3}{ }^{2+}$ (Figure 1 ). The structure 1 is characterized with a two-electron three-center (2e-3c) bond, a two-electron two-center (2e-2c) bond, resembling a complex between $\mathrm{BH}^{2+}$ and $\mathrm{H}_{2}$. The $\mathrm{B}-\mathrm{H}$ and $\mathrm{H}-\mathrm{H}$ bond distances of the $2 \mathrm{e}-3 \mathrm{c}$ bond are computed to be $1.491 \AA$ and $0.889 \AA$, respectively. Expectedly, both thermodynamically and kinetically the dication is unstable due to charge-charge repulsion. The dissociation of 1 into $\mathrm{BH}_{2}^{+}$and $\mathrm{H}^{+}$is exothermic by $100.6 \mathrm{kcal} / \mathrm{mol}$ and the process has a kinetic barrier of $8.2 \mathrm{kcal} / \mathrm{mol}$ at the CCSD(T)/cc-pVTZ//CCSD(T)/cc-pVTZ + ZPE level (Table 2).

Previously we have reported ${ }^{7}$ the $\mathrm{MP} 2 / 6-31 \mathrm{G}^{* *}$ calculated structure of the boronium ion $\mathrm{BH}_{4}^{+} \mathbf{2}$. $\mathrm{The}^{2}$ structure of $\mathrm{BH}_{4}{ }^{+}$was found to be isostructural with the corresponding carbon analog $\mathrm{CH}_{4}{ }^{2+} .16$ DePuy et al were able to generate $\mathrm{BH}_{4}{ }^{+} 2$ in the gas phase by the reaction of $\mathrm{BH}_{2}{ }^{+}$and $\mathrm{H}_{2} .{ }^{17}$ Removal of an electron from $\mathrm{BH}_{4}+2$ leads to the dication $\mathrm{BH}_{4}{ }^{2+} 3$. The planar $\mathrm{D}_{2} \mathrm{~h}$ symmetric form 3 (Figure 1 ) is found to be the only minimum on the potential energy surface of $\mathrm{BH}_{4}{ }^{2+}$. Structure 3 resembles a complex between $\mathrm{B}^{2+}$ with two hydrogen molecules resulting in formation of two $2 \mathrm{e}-3 \mathrm{c}$ bonds. Deprotonation of $\mathbf{3}$ has a substantial kinetic barrier of $24.7 \mathrm{kcal} / \mathrm{mol}$ (although exothermic by $68.7 \mathrm{kcal} / \mathrm{mol}$, Table 1). Despite charge-charge repulsion the $2 \mathrm{e}-3 \mathrm{c}$ B-H bond distance of dication 3 (1.320 $\mathrm{A})$ is considerably shorter than that of monocation 2 (1.422 $\mathrm{A})$. 
Protonation of $\mathrm{BH}_{4}+2$ leads to the dication $\mathrm{BH}_{5}{ }^{2+} 4$. We previously reported 18 the structure of $\mathrm{BH}_{5}{ }^{2+}$ at the QCISD(T)/6-311G** level. CCSD(T)/cc-pVTZ optimized structure of $\mathrm{BH}_{5}{ }^{2+} 4$ is now computed and displayed in Figure 1. The structure 4 resembles a complex between $\mathrm{BH}^{2+}$ and two $\mathrm{H}_{2}$ molecules resulting in formation of two $2 \mathrm{e}-3 \mathrm{c}$ bonds with an empty p-orbital orthogonal to the plane of the molecule. The dissociation of 4 into $\mathrm{BH}_{4}+2$ and $\mathrm{H}^{+}$was calculated to be exothermic by $56.6 \mathrm{kcal} / \mathrm{mol}$ but has a high kinetic barrier of $36.5 \mathrm{kcal} / \mathrm{mol}$ (Table 2).

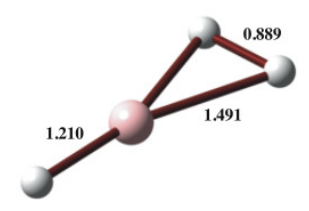

$1 \mathrm{BH}_{3}{ }^{2+}\left(\mathrm{C}_{2} \mathrm{v}\right)$

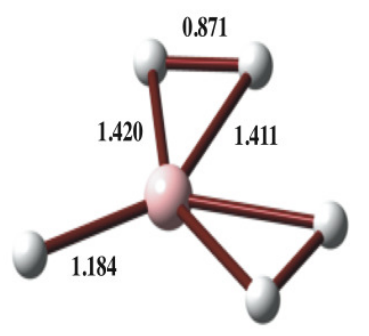

$4 \mathrm{BH}_{5}{ }^{2+}\left(\mathrm{C}_{2} \mathrm{v}\right)$

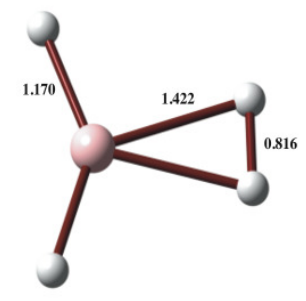

$2 \mathrm{BH}_{4}+\left(\mathrm{C}_{2} \mathrm{v}\right)$

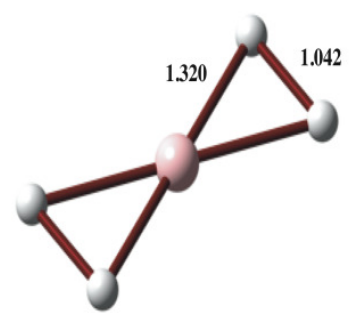

$3 \mathrm{BH}_{4}{ }^{2+}\left(\mathrm{D}_{2} \mathrm{~h}\right)$

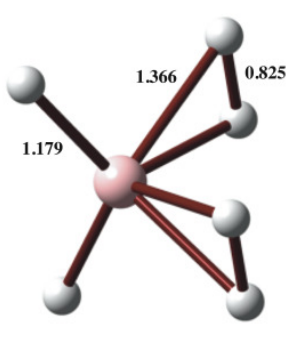

$5 \mathrm{BH}_{6}+\left(\mathrm{C}_{2} \mathrm{v}\right)$

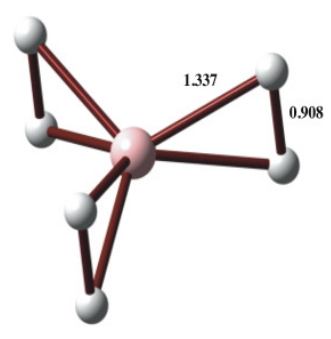

$6 \mathrm{BH}_{6}{ }^{2+}\left(\mathrm{D}_{3} \mathrm{~d}\right)$

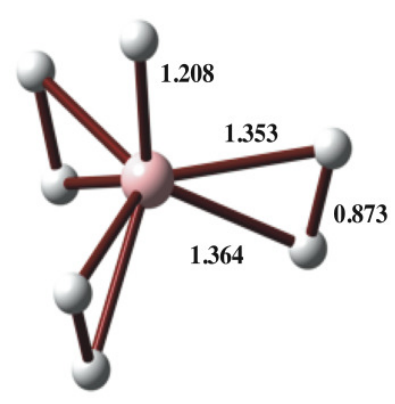

$7 \mathrm{BH}^{2+}\left(\mathrm{C}_{3} \mathrm{v}\right)$

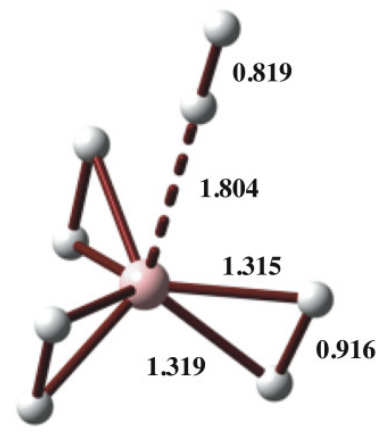

$8 \mathrm{BH}_{8}^{2+}\left(\mathrm{C}_{3} \mathrm{v}\right)$

Figure 1. $\operatorname{CCSD}(\mathrm{T}) / \mathrm{cc}-\mathrm{pVTZ}$ calculated structures of $\mathbf{1} \mathbf{-} \mathbf{8}$.

The parent hexacoordinated boronium ion $\mathrm{BH}_{6}{ }^{+} \mathbf{5}$ is isoelectronic and isostructural with the corresponding carbon analog $\mathrm{CH}_{6}{ }^{2+} .8,9$ The ion 5 was studied previously by us. ${ }^{2}$ DePuy et al. were able to generate 5 in the gas phase by the reaction of $\mathrm{BH}_{4}+2$ and $\mathrm{H}_{2} \cdot{ }^{12}$ The $\mathrm{C}_{2} v$ symmetric form 5 was found to be the only minimum for $\mathrm{BH}_{6}{ }^{+} .5$ contains two $2 \mathrm{e}-3 \mathrm{c}$ bonds and two 2c-2e bonds. Calculated B-H bond distance of 2e-3c interactions is found to be $1.366 \AA$. Removal of an electron from $\mathrm{BH}_{6}{ }^{+} 5$ leads to dication $\mathrm{BH}_{6}{ }^{2+} 6$. The $\mathrm{D}_{3 \mathrm{~d}}$ symmetric 6 is 
a propeller-shaped molecule resembling a complex between $\mathrm{B}^{2+}$ with three hydrogen molecules resulting in formation of three $2 \mathrm{e}-3 \mathrm{c}$ bonds. B-H bond distance of $2 \mathrm{e}-3 \mathrm{c}$ interactions of the structure 6 is computed to be $1.337 \AA$ A. Deprotonation of 6 has a high kinetic barrier of $52.5 \mathrm{kcal} / \mathrm{mol}$ (Table 2).

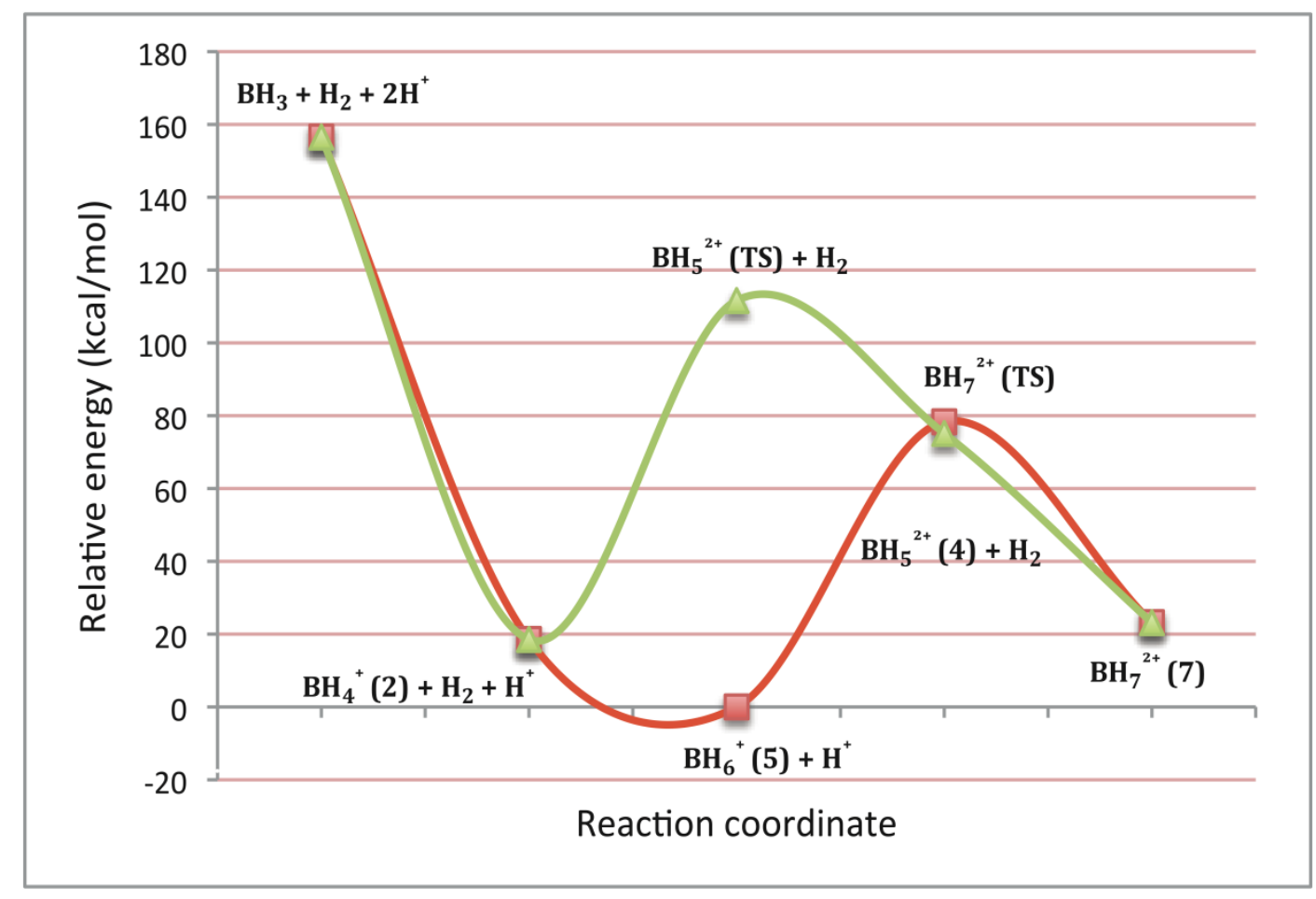

Figure 2. Plot of relative energy of the structures, 2, 4, 5 and $\mathbf{7 .}$

Protonation of $\mathrm{BH}_{6}{ }^{+} 5$ leads to heptacoordinate boronium dication $\mathrm{BH}_{7}^{2+}$ 7. The $\mathrm{C}_{3} v$ symmetric dication 7 is also propeller-shaped resembling a complex between $\mathrm{BH}^{2+}$ with three hydrogen molecules resulting in formation of three $2 \mathrm{e}-3 \mathrm{c}$ bonds. Average $\mathrm{B}-\mathrm{H}$ bond distances of $2 \mathrm{e}-3 \mathrm{c}$ interactions of the structure 7 is found to be $1.359 \AA$ A. Deprotonation of 7 into $\mathrm{BH}_{6}{ }^{+} \mathbf{5}$ is exothermic by only $23.2 \mathrm{kcal} / \mathrm{mol}$ and the process has a high kinetic barrier of $55.1 \mathrm{kcal} / \mathrm{mol}$ at the CCSD(T)/cc-pVTZ//CCSD(T)/cc-pVTZ + ZPE level (Table 1). Relative energies of the structures 2, 4, 5, $\mathbf{7}$ are plotted in Figure 2.

We also searched for any eight coordinate energy-minimum for dication $\mathrm{BH}_{8}{ }^{2+}$. The structure 8 was found to be a minimum on the potential energy surface of $\mathrm{BH}_{8}{ }^{2+}$ (Figure 1). The $\mathrm{C}_{3} \mathrm{v}$ symmetrical structure 8 can be considered as a weak complex between $\mathrm{BH}_{6}{ }^{2+} 6$ and $\mathrm{H}_{2}$ with a long bond distance of $1.844 \AA$ between boron atom and $\mathrm{H}_{2}$ moiety.

\section{$\mathrm{B}_{2} \mathrm{H}_{2} \mathrm{n}^{2+}(\mathrm{n}=2-4)$ systems}

In line with previous calculations at the $\mathrm{QCISD}(\mathrm{T}) / 6-311 \mathrm{G}^{* *}$ level, 12 our present calculations at the $\operatorname{CCSD}(T) / c c-p V T Z$ level also shows that the $C_{S}$ symmetric structure $\mathbf{9}$ and $D_{2} h$ symmetric structure 10 are the viable minima for $\mathrm{B}_{2} \mathrm{H}_{4}{ }^{2+}$ (Figure 4). Structure 9 resembles a complex between $\mathrm{B}_{2} \mathrm{H}_{2}{ }^{2+}$ and $\mathrm{H}_{2}$ resulting in the formation of a $2 \mathrm{e}-3 \mathrm{c}$ bond. Structure $\mathbf{1 0}$ is characterized as a doubly hydrogen-bridged structure. 
Structure 9 is $9.4 \mathrm{kcal} / \mathrm{mol}$ more stable than 10. The dissociation of 9 into $\mathrm{B}_{2} \mathrm{H}_{3}{ }^{+}$and $\mathrm{H}^{+}$was computed to be exothermic by $6.7 \mathrm{kcal} / \mathrm{mol}$ but has a high kinetic barrier of $61.6 \mathrm{kcal} / \mathrm{mol}$ (Table 2).

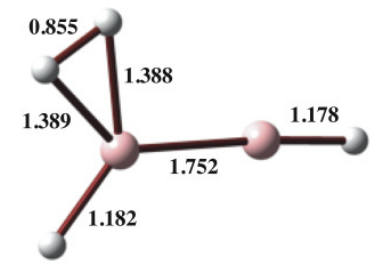

$9 \mathrm{~B}_{2} \mathrm{H}_{4}{ }^{2+}\left(\mathrm{C}_{\mathrm{S}}\right)$

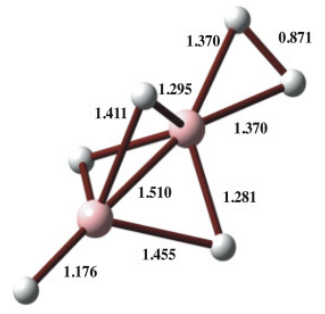

$12 \mathrm{~B}_{2} \mathrm{H}_{6}{ }^{2+}\left(\mathrm{C}_{\mathrm{s}}\right)$

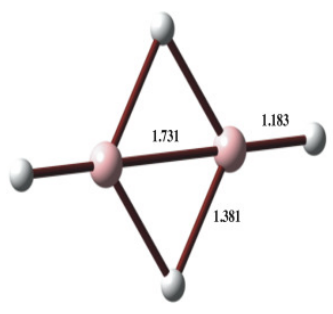

$10 \mathrm{~B}_{2} \mathrm{H}_{4}{ }^{2+}\left(\mathrm{D}_{2} \mathrm{~h}\right)$

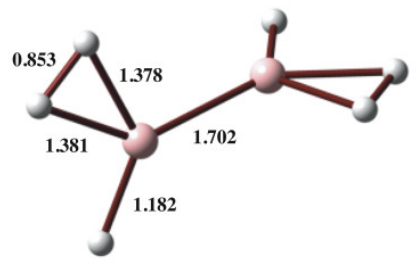

$13 \mathrm{~B}_{2} \mathrm{H}_{6}{ }^{2+}\left(\mathrm{C}_{2}\right)$

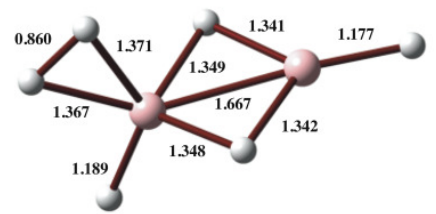

$11 \mathrm{~B}_{2} \mathrm{H}_{6}{ }^{2+}\left(\mathrm{C}_{\mathrm{s}}\right)$

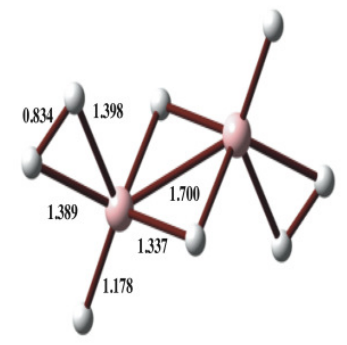

$14 \mathrm{~B}_{2} \mathrm{H}_{8}{ }^{2+}\left(\mathrm{C}_{\mathrm{i}}\right)$

Figure 3. $\operatorname{CCSD}(\mathrm{T}) / \mathrm{cc}-\mathrm{pVTZ}$ calculated structures of $\mathbf{9} \mathbf{- 1 4}$.

Table 1. Total energies (-au), ZPE ( $\mathrm{kcal} / \mathrm{mol}$ ) and relative energies (RA in $\mathrm{kcal} / \mathrm{mol}$ )

\begin{tabular}{ccccc}
\hline No. & MP2/cc-pVTZ & ZPEa & CCSD(T)/cc-pVTZ & RA $^{b}$ \\
\hline $\mathbf{1}$ & 25.39039 & 12.7 & 25.41983 & \\
$\mathbf{2}$ & 26.74205 & 21.9 & 26.78047 & \\
$\mathbf{3}$ & 25.96738 & 15.9 & 26.00121 & \\
$\mathbf{4}$ & 26.65701 & 25.2 & 26.69554 & \\
$\mathbf{5}$ & 27.94345 & 34.2 & 27.99208 & \\
$\mathbf{6}$ & 27.24920 & 31.5 & 27.29300 & \\
$\mathbf{7}$ & 27.91237 & 38.5 & 27.96199 & \\
$\mathbf{8}$ & 28.42359 & 38.9 & 28.47827 & \\
$\mathbf{9}$ & 50.90219 & 23.3 & 50.96293 & 0.0 \\
$\mathbf{1 0}$ & 50.88575 & 22.8 & 50.94717 & 9.4 \\
$\mathbf{1 1}$ & 52.13230 & 35.5 & 52.20481 & 0.7 \\
$\mathbf{1 2}$ & 52.13278 & 35.3 & 52.20553 & 0.0 \\
$\mathbf{1 3}$ & 52.12357 & 34.7 & 52.19450 & 6.3 \\
$\mathbf{1 4}$ & 53.35921 & 47.9 & 53.44053 & \\
\hline
\end{tabular}

aZPE at the MP2/cc-pVTZ//MP2/cc-pVTZ level level scaled by a factor of 0.96;

bat the CCSD(T)/cc-pVTZ//CCSD(T)/cc-pVTZ + ZPE (MP2/cc-pVTZ//MP2/cc-pVTZ) level. 
Three viable minimum structures (11-13) were computed for the diboronium dication, $\mathrm{B}_{2} \mathrm{H}_{6}{ }^{2+}$ (Figure 4). Triply hydrogen-bridged structure $\mathbf{1 2}$ was found to be the lowest minimum. This structure $\mathbf{1 2}$ also contains a $2 \mathrm{e}-3 \mathrm{c}$ bond involving a boron atom and two hydrogen atoms. One of the borons in structure $\mathbf{1 2}$ is sixcoordinated and the other one is five-coordinated. Dication 11, on the other hand, is doubly hydrogen-bridged structure. Additionally it also contains a $2 \mathrm{e}-3 \mathrm{c}$ bond involving a boron atom and two hydrogen atoms. Structure 11 is only $0.7 \mathrm{kcal} / \mathrm{mol}$ less stable than $\mathbf{1 2}$. Structure 13, unlike structures 11 and 12, was characterized to be a non-hydrogen-bridged (involving both boron atoms) structure. Dication 13 with two $2 \mathrm{e}-3 \mathrm{c}$ bonds can be considered as a complex between $\mathrm{B}_{2} \mathrm{H}_{2}{ }^{2+}$ and two hydrogen molecules. Structure 13 is 6.3 $\mathrm{kcal} / \mathrm{mol}$ less stable than the structure 12. The dissociation of $\mathbf{1 2}$ into $\mathrm{B}_{2} \mathrm{H}_{5}{ }^{+}$and $\mathrm{H}^{+}$was calculated to be exothermic by $33.9 \mathrm{kcal} / \mathrm{mol}$ but has a kinetic barrier of $45.1 \mathrm{kcal} / \mathrm{mol}$ (Table 2).

Table 2. Dissociation Energy $\left(\Delta E_{0}\right)$ and Respective Kinetic Barrier at $298 \mathrm{~K}$ for the Selected Processesa

\begin{tabular}{|c|c|c|}
\hline Process & $\Delta E_{0}(\mathrm{kcal} / \mathrm{mol})^{\mathrm{b}}$ & Barrier $(\mathrm{kcal} / \mathrm{mol})^{b}$ \\
\hline $\mathrm{BH}_{3}{ }^{2+}(\mathbf{1})--->\mathrm{BH}_{2}{ }^{+}+\mathrm{H}^{+}$ & -100.6 & 8.2 \\
\hline $\mathrm{BH}_{4}{ }^{2+}(3)--->\mathrm{BH}_{3}++\mathrm{H}^{+}$ & -68.7 & 20.2 \\
\hline $\mathrm{BH}_{5}{ }^{2+}(4)--->\mathrm{BH}_{4}{ }^{+}+\mathrm{H}^{+}$ & -56.6 & 36.5 \\
\hline $\mathrm{BH}_{6}^{2+}(6)--->\mathrm{BH}_{5}{ }^{+}+\mathrm{H}^{+}$ & -25.8 & 52.5 \\
\hline $\mathrm{BH}_{7}^{2+}(7)-->\mathrm{BH}_{6}^{+}+\mathrm{H}^{+}$ & -23.2 & 55.1 \\
\hline $\mathrm{B}_{2} \mathrm{H}_{4}{ }^{2+}(9)--->\mathrm{B}_{2} \mathrm{H}_{3}{ }^{+}+\mathrm{H}^{+}$ & -6.7 & 61.6 \\
\hline $\mathrm{B}_{2} \mathrm{H}_{6}{ }^{2+}(12)-->\mathrm{B}_{2} \mathrm{H}_{5}{ }^{+}+\mathrm{H}^{+}$ & -33.9 & 45.1 \\
\hline
\end{tabular}

$a_{a t}$ the $\operatorname{CCSD}(T) / c c-p V T Z / / \operatorname{CCSD}(T) / c c-p V T Z+Z P E(M P 2 / c c-p V T Z / / M P 2 / c c-p V T Z$ level scaled by a factor of 0.96$)$ level.

Structure 14 was computed for diprotonated diborane $\mathrm{B}_{2} \mathrm{H}_{8}{ }^{2+}$. Dication 14 is a doubly hydrogen-bridged structure. It was also characterized to possess two $2 e-3 c$ bonds. Structure 14 (Figure 3) contains two six coordinate boron atoms. The structure formally resembles a complex between a $\mathrm{B}_{2} \mathrm{H}_{4}{ }^{2+} 10$ with two hydrogen molecules resulting in formation of two $2 e-3 c$ bonds. Calculated central B-B bond length of 14 is computed to be $1.700 \AA$.

\section{Conclusions}

Structures of higher coordinate hydrido boronium dications were calculated using CCSD(T)/cc-pVTZ level of theory and compared with their isoelectronic carbon analogs. These calculations indicate that higher coordinated doubly charged boronium dications are viable species in the gas phase despite strong chargecharge repulsion. In such small first row highly charged cations, charge-charge repulsions are clearly substantial, but the bonding interactions are strong enough to counter this. Although such hydrido boronium dications are thermodynamically unstable, their computational characterization gives support for their transient existence. Structures, stability and multicenter bonding concept of the intriguing higher coordinate boronium and carbonium (hypercarbon) ${ }^{19}$ ions as well characterized compounds have now been 
calculationally established. By development of new techniques, the characterization of these intriguing species is considered possible.

\section{Acknowledgements}

Support of our work by the Loker Hydrocarbon Research Instititue is gratefully acknowledged.

\section{References}

1. Koch, W.; Schwarz, H.; Structure / Reactivity and Thermochemistry of Ions; Ausloos, P.; Lias, S. G., Eds.; Reidel: Dordrecht, 1987, p 413.

https://doi.org/10.1007/978-94-009-3787-1 21

2. Lammertsma, K.; Schleyer, P. v. R.; Schwarz, H. Angew. Chem. Int. Ed. Engl. 1989, $28,1321$. https://doi.org/10.1002/anie.198913211

3. Lammertsma, K. Rev. Chem. Intermed. 1988, 9, 141. https://doi.org/10.1007/BF03155682

4. Koch, W.; Maquin, F.; Stahl, D.; Schwarz, H. Chimica 1985, 39, 376.

5. Schleyer, P. v. R.; Adv. Mass. Spectrom. 1986, 10, 287.

6. Olah, G.A. Angew. Chem. Int. Ed. Engl. 1993, 32, 767.

https://doi.org/10.1002/anie.199307673

7. Rasul, G.; Olah, G. A., Inorg. Chem., 1997, 36, 1278.

https://doi.org/10.1021/ic960843k

8. Lammertsma, K.; Olah. G. A.; Barzaghi, M.; Simonetta, M.; J. Am. Chem. Soc., 1982, 104, 6851. https://doi.org/10.1021/ja00388a095

9. Lammertsma, K.; Barzaghi, M.; Olah. G. A.; Pople, J. A.; Schleyer, P. v. R.; Simonetta, M.; J. Am. Chem. Soc., 1983, 105, 5258.

https://doi.org/10.1021/ja00354a013

10. Olah. G. A.; Rasul, G.; J. Am. Chem. Soc., 1996, 118, 8503.

https://doi.org/10.1021/ja961081v

11. Rasul, G.; Dias, J. F.; Seidl, P. R.; Prakash, G. K. S., Olah, G. A., J. Phys. Chem. A, 2003, 107, 4731. https://doi.org/10.1021/jp0226735

12. Dias, J. F.; Rasul, G.; Seidl, P. R.; Prakash, G. K. S., Olah, G. A., J. Phys. Chem. A, 2003, 107, 7981. https://doi.org/10.1021/jp0307405

13. Gaussian 09, Revision A.02, Frisch, M. J.; Trucks, G. W.; Schlegel, H. B.; Scuseria, G. E.; Robb, M. A.; Cheeseman, J. R.; Scalmani, G.; Barone, V.; Mennucci, B.; Petersson, G. A.; Nakatsuji, H.; Caricato, M.; Li, X.; Hratchian, H. P.; Izmaylov, A. F.; Bloino, J.; Zheng, G.; Sonnenberg, J. L.; Hada, M.; Ehara, M.; Toyota, K.; Fukuda, R.; Hasegawa, J.; Ishida, M.; Nakajima, T.; Honda, Y.; Kitao, O.; Nakai, H.; Vreven, T.; Montgomery, Jr., J. A.; Peralta, J. E.; Ogliaro, F.; Bearpark, M.; Heyd, J. J.; Brothers, E.; Kudin, K. N.; Staroverov, V. N.; Kobayashi, R.; Normand, J.; Raghavachari, K.; Rendell, A.; Burant, J. C.; lyengar, S. S.; Tomasi, J.; Cossi, M.; Rega, N.; Millam, N. J.; Klene, M.; Knox, J. E.; Cross, J. B.; Bakken, V.; Adamo, C.; 
Jaramillo, J.; Gomperts, R.; Stratmann, R. E.; Yazyev, O.; Austin, A. J.; Cammi, R.; Pomelli, C.; Ochterski, J. W.; Martin, R. L.; Morokuma, K.; Zakrzewski, V. G.; Voth, G. A.; Salvador, P.; Dannenberg, J. J.; Dapprich, S.; Daniels, A. D.; Farkas, Ö.; Foresman, J. B.; Ortiz, J. V.; Cioslowski, J.; Fox, D. J. Gaussian, Inc., Wallingford CT, 2009.

14. Alecu, I. M.; Zheng, J.; Zhao, Y.; Truhlar, D. G. J. Chem. Theory Comput. 2010, 6, 2872. https://doi.org/10.1021/ct100326h

15. CFOUR, a quantum chemical program package, Stanton, J. F.; Gauss, J.; Harding, M. E.; Szalay, P. G. with contributions from Auer, A. A.; Bartlett, R. J.; Benedikt, U.; Berger, C.; Bernholdt, D. E.; Bomble, Y. J.; Cheng, L.; Christiansen, O.; Heckert, M.; Heun, O.; Huber, C.; Jagau, C.; Jonsson, D.; Jusélius, J.; Klein, K.; Lauderdale, W. J.; Mathews, D. A.; Metzroth, T.; O’Neill, D. P.; Price, D. R.; Prochnow, E.; Ruud, K.; Schiffmann, F.; Schwalbach, W.; Stopkowicz, S.; Tajti, A.; Vuzquez, J.; Wang, F.; Watts, J. D.; and the integral packages MOLE-CULE (Almlçf, J and Taylor, P. R.), PROPS (Taylor, P. R.), ABACUS (Helgaker, T.; Aa, H. J.; Jensen H. J. A.; Jørgensen, P.; Olsen, J.), and ECP routines (Mitin, A. V.; Wüllen, C. van), 2010; Harding, M. E.; Metzroth, T.; Gauss, J.; Auer, A. A. J. Chem. Theory Comput. 2008, 4, 64.

16. Wong, M. W.; Radom, L. J. Am. Chem. Soc. 1989, 111, 1155.

https://doi.org/10.1021/ja00185a070

17. DePuy, C. H.; Gareyev, R.; Hankin, J.; Davico, G. E. J. Am. Chem. Soc. 1997, 119, 427. https://doi.org/10.1021/ja963399t

18. Olah, G. A.; Rasul, G. J. Am. Chem. Soc., 1996, 118, 12922. https://doi.org/10.1021/ja961597e

19. Olah, G. A.; Prakash, G. K. S.; Wade, K.; Molnar, A.; Williams, R. E. Hypercarbon Chemistry, John Wiley \& Sons: New York, 2011.

https://doi.org/10.1002/9781118016466 